\title{
Reply to "Consequences of dike breaches and dike overflow in a bifurcating river system"
}

\author{
A. Bomers ${ }^{1}$ (D) R. M. J. Schielen ${ }^{1,2}$. S. J. M. H. Hulscher ${ }^{1}$
}

Received: 25 June 2020 / Accepted: 4 July 2020 / Published online: 16 July 2020

(c) The Author(s) 2020

\begin{abstract}
In this reply, we would like to comment on the discussion paper of AlQasimi and Mahdi (Nat Hazards 97:1-4, 2020. https://doi.org/10.1007/s11069-020-03904-1). We discuss their view and possible improvements of the paper of Bomers et al. (Nat Hazards 97(1):309334, 2019b. https://doi.org/10.1007/s11069-019-03643-y) in more detail and explain how large-flood modelling methods can benefit from the suggestions given by AlQasimi and Mahdi (2020).
\end{abstract}

Keywords Discharge propagation · Monte Carlo analysis · Manning's coefficient

\section{Introduction}

Bomers et al. (2019b) studied the effect of dike breaches and overflow on downstream flow patterns and discharge partitioning. The Rhine delta was used as a case study. A onedimensional-two dimensional (1D-2D) coupled hydraulic model (HEC-RAS v. 5.0.3) was used to simulate discharge propagation from Andernach, Germany, to the Dutch deltaic area. A Monte Carlo analysis was performed to study the effect of dike breaches on overland flow patterns. Only the parameters influencing the dike breach outflow were included as uncertain input parameters in the analysis. In the discussion of AlQasimi and Mahdi (2020), the following limitations of the proposed method in Bomers et al. (2019b) are described:

- The 2D mesh resolution can have a significant effect on model results, while this problem has not been addressed in Bomers et al. (2019b).

- A 1D-2D coupled modelling approach introduces modelling errors, especially near rivers' bifurcation points.

- The software HEC-RAS (v. 5.0.3), developed by the Hydrologic Engineering Centre (HEC) of the US Army Corps of Engineers, overestimates the prediction of numerical diffusion affecting simulated velocity profiles and water levels.

A. Bomers

a.bomers@utwente.nl

1 University of Twente, Dienstweg 1, Enschede, The Netherlands

2 Ministry of Infrastructure and Water Management-Rijkswaterstaat, Arnhem, The Netherlands 
- Both downstream boundary conditions and bed friction influence model results, and therefore, their uncertainties must be included in the analysis.

In this reply, we describe our view on these limitations and give recommendations to improve large-flood modelling approaches.

\section{The effect of mesh resolution on model results}

We agree with AlQasimi and Mahdi (2020) that much attention should be paid to the numerical mesh size. Bomers et al. (2019c) and Caviedes-Voullième et al. (2012) show that an increase in the numerical mesh resolution results in a decrease in the predicted water levels and that this effect might be larger than generated by physical bed friction. However, AlQasimi and Mahdi (2020) argue that increasing the mesh resolution in HECRAS v. 5.0.3 by a factor two may result in an increase in the water depth by a factor 20 , which contradicts the work of Bomers et al. (2019c) and Caviedes-Voullième et al. (2012). To study the sensitivity of the mesh resolution on the modelled water depths in the work of Bomers et al. (2019b), an additional run was performed in which the mesh resolution was increased with a factor two from $150 \times 150 \mathrm{~m}$ to $75 \times 75 \mathrm{~m}$. It was found that water levels in the Old IJssel Valley, the location of main interest, decreased on average with $8 \mathrm{~cm}$ due to this increase in mesh resolution. This corresponds to an average decrease of $8 \%$ in water depth. Please note that the choice of the mesh resolution only influences model results in the hinterland since the main channels and their floodplains are discretized by 1D profiles. Therefore, the timing and locations of the dike breaches do not change. We thus conclude that the mesh size used by Bomers et al. (2019b) is appropriate. However, we do agree with AlQasimi and Mahdi (2020) that the choice of mesh size is highly important and we suggest to further study its effect on model results during large-flood events in future research.

\section{A 1D-2D coupled model in HEC-RAS v. 5.0.3}

Bomers et al. (2019b) used a 1D-2D coupled model since solving the main channels and their floodplains with 1D profiles result in a significant reduction in computational times. Furthermore, the literature shows that 1D profiles give an accurate representation of flood wave propagation in case of in-channel flows where there is a strong dominant flow direction (Bomers et al. 2019b; Tayefi et al. 2007). However, as AlQasimi and Mahdi (2020) already suggest, a 1D-2D coupling may introduce errors in the model, especially near rivers' bifurcations. Therefore, it is highly important that next to water levels also discharge partitioning is validated after model calibration.

Furthermore, it was found that the use of the diffusive wave equations in HEC-RAS v. 5.0.3 may result in flattening of the velocity profiles across the direction of the flow caused by problems related to the numerical diffusion in the advection terms (USACE 2019). The computation scheme in HEC-RAS has been updated, and the new results in v. 5.0.7 will have less numerical diffusion, resulting in potentially higher flow velocities and lower water levels. USACE (2019) mention that developed models in v. 5.0.3 may require a minor adjustment in the Manning's roughness coefficients in order to reproduce previous results in v. 5.0.7. Since only a minor adjustment is required, it is expected that the effects of the new computation scheme on model results are only small. 
Furthermore, the limitations of HEC-RAS v. 5.0 .3 only influenced the results in the hinterland which was discretized on a 2D grid in the work of Bomers et al. (2019b). The rivers were represented by $1 \mathrm{D}$ profiles and hence not affected by the changes in the $2 \mathrm{D}$ numerical scheme. The water levels and discharge partitionings of the rivers were calibrated using measured water levels and derived discharges as validation data, resulting in accurate results. However, we do recommend to use HEC-RAS v. 5.0.7 in future work.

\section{The downstream boundary conditions}

Bomers et al. (2019b) used normal depths computed with the Manning's equation as downstream boundary conditions for both the main channels and their floodplains as well as for the hinterland to ensure that the overland flow patterns could leave the model domain. The Manning's equation requires a user-entered energy slope which can be estimated by the slope of the terrain (Brunner 2016). The Manning's equation computes the water levels at the downstream boundaries based on simulated flow velocities.

For subcritical flow, the boundary conditions have a significant effect on the model results due to backwater curves. Therefore, as a general rule, the downstream boundaries should be sufficiently downstream such that the conditions do not influence the results in the area of interest. To study the effect of the downstream boundaries on the studied area in Bomers et al. (2019b), the user-entered energy slopes were increased with a factor two. It was indeed found that this increase results in a significant change in the simulated water levels close to the boundaries. However, at Doesburgbrug, representing the most downstream measurement location along the IJssel River used for model calibration, an increase in the maximum water level of only $1.0 \mathrm{~cm}$ was found. Furthermore, the discharge of the IJssel River increased with $1.6 \%$ and the discharge through the Old IJssel Valley with $0.6 \%$. These small changes can be neglected with respect to the overall model uncertainty.

\section{Manning's roughness uncertainties}

Bomers et al. (2019b) altered the main channel friction values to compensate for errors in the input parameters and model approach during the calibration. Consequently, uncertainties related to the bed friction were not included in the analysis. However, we do agree with AlQasimi and Mahdi (2020) that uncertainties related to the friction description should be included in the analysis to get a fair estimate of the total model output uncertainty even though this requires an extensive Monte Carlo analysis. Therefore, we recommend to include the calibrated main channel friction values as a stochastic parameter in the analysis. Furthermore, Bomers et al. (2019a) showed that for the Rhine River, particularly the uncertainties related to grasslands in the floodplains influence model results. Also including these uncertainties in the analysis leads to more accurate potential flood scenarios since the friction directly influences the simulated water levels in the rivers and hence the timing of dike breaches. 


\section{Recommendations}

Based on the work of AlQasimi and Mahdi (2020) and Bomers et al. (2019b), we give the following two recommendations to increase the accuracy of model results for large-flood modelling purposes:

- AlQasimi and Mahdi (2020) argue that increasing the mesh resolution results in an increase in simulated water levels. However, this statement contradicts the findings of Bomers et al. (2019c) and Caviedes-Voullième et al. (2012). Therefore, we recommend to study the effect of 2D mesh resolutions on model results during large-flood events in more detail for future work.

- The bed friction is a large source of uncertainty. During model calibration, the main channel friction is generally altered to compensate for errors in the input parameters and model approach. It is recommended to include this calibrated main channel friction as a stochastic parameter in a Monte Carlo analysis to get a fair estimate of the total model output uncertainty.

Acknowledgements This research was supported by the Netherlands Organisation for Scientific Research (NWO, Project 14506) which was partly funded by the Ministry of Economic Affairs and Climate Policy. Furthermore, the research was supported by the Ministry of Infrastructure and Water Management and Deltares.

Open Access This article is licensed under a Creative Commons Attribution 4.0 International License, which permits use, sharing, adaptation, distribution and reproduction in any medium or format, as long as you give appropriate credit to the original author(s) and the source, provide a link to the Creative Commons licence, and indicate if changes were made. The images or other third party material in this article are included in the article's Creative Commons licence, unless indicated otherwise in a credit line to the material. If material is not included in the article's Creative Commons licence and your intended use is not permitted by statutory regulation or exceeds the permitted use, you will need to obtain permission directly from the copyright holder. To view a copy of this licence, visit http://creativecommons.org/licenses/by/4.0/.

\section{References}

AlQasimi E, Mahdi TF (2020) Discussion of Consequences of dike breaches and dike overflow in a bifurcating river system by Anouk Bomers, Ralph M. J. Schielen and Suzanne J. M. H. Hulscher. Nat Hazards. https://doi.org/10.1007/s11069-020-03904-1

Bomers A, Schielen RMJ, Hulscher SJMH (2019a) Application of a lower-fidelity surrogate hydraulic model for historic flood reconstruction. Environ Model Softw 117:223-236. https://doi.org/10.1016/j. envsoft.2019.03.019

Bomers A, Schielen RMJ, Hulscher SJMH (2019b) Consequences of dike breaches and dike overflow in a bifurcating river system. Nat Hazards 97(1):309-334. https://doi.org/10.1007/s11069-019-03643-y

Bomers A, Schielen RMJ, Hulscher SJMH (2019c) The influence of grid shape and grid size on river modelling performance. Environ Fluid Mech 19(5):1273-1294. https://doi.org/10.1007/s10652-019-09670 $-4$

Brunner GW (2016) HEC-RAS, hydraulic reference manual, version 5.0. Technical report, US Army Corp of Engineers, Hydrologic Engineering Center (HEC), Davis, USA. https://www.hec.usace.army.mil/ software/hec-ras/documentation/HEC-RAS 5.0 Reference Manual.pdf

Caviedes-Voullième D, García-navarro P, Murillo J (2012) Influence of mesh structure on 2D full shallow water equations and SCS curve number simulation of rainfall/runoff events. J Hydrol 448(449):39-59. https://doi.org/10.1016/j.jhydrol.2012.04.006

Tayefi V, Lane SN, Hardy RJ, Yu D (2007) A comparison of one- and two-dimensional approaches to modelling flood inundation over complex upland floodplains. Hydrol Process 21:3190-3202. https://doi. org/10.1002/hyp.6523 
USACE (2019) HEC-RAS release notes version 5.0.7. Technical report, March, CPD-68. https://www.hec. usace.army.mil/software/hec-ras/documentation/HEC-RAS_5.0.7_Release_Notes.pdf

Publisher's Note Springer Nature remains neutral with regard to jurisdictional claims in published maps and institutional affiliations. 